OPEN ACCESS

Edited by: Steven Frucht,

Mount Sinai Hospital, United States

Reviewed by:

Pedro Ribeiro,

Federal University of Rio de

Janeiro, Brazi

Graziella Madeo,

Fondazione Novella Fronda

Onlus, Italy

${ }^{*}$ Correspondence:

Li Cao

caoli2000@yeah.net

Specialty section:

This article was submitted to

Movement Disorders,

a section of the journal

Frontiers in Neurology

Received: 25 January 2020

Accepted: 13 July 2020

Published: 25 August 2020

Citation:

Wu J, Tang H, Chen S and Cao L

(2020) Mechanisms and

Pharmacotherapy for Ethanol-Responsive Movement

Disorders. Front. Neurol. 11:892. doi: 10.3389/fneur.2020.00892

\section{Mechanisms and Pharmacotherapy for Ethanol-Responsive Movement Disorders}

\author{
Jingying Wu, Huidong Tang, Shengdi Chen and Li Cao* \\ Department of Neurology and Institute of Neurology, Rui Jin Hospital, Shanghai Jiao Tong University School of Medicine, \\ Shanghai, China
}

Ethanol-responsive movement disorders are a group of movement disorders of which clinical manifestation could receive significant improvement after ethanol intake, including essential tremor, myoclonus-dystonia, and some other hyperkinesia. Emerging evidence supports that the sensitivity of these conditions to ethanol might be attributed to similar anatomical targets and pathophysiologic mechanisms. Cerebellum and cerebellum-related networks play a critical role in these diseases. Suppression of inhibitory neurotransmission and hyper-excitability of these regions are the key points for pathogenesis. GABA pathways, the main inhibitory system involved in these regions, were firstly linked to the pathogenesis of these diseases, and $G_{A B A_{A}}$ receptors and $G_{A B A}$ receptors play critical roles in ethanol responsiveness. Moreover, impairment of low-voltage-activated calcium channels, which were considered as a contributor to oscillation activity of the nervous system, also participates in the sensitivity of ethanol in relevant disease. Glutamate transporters and receptors that are closely associated with GABA pathways are the action sites for ethanol as well. Accordingly, alternative medicines aiming at these shared mechanisms appeared subsequently to mimic ethanol-like effects with less liability, and some of them have achieved positive effects on different diseases with well-tolerance. However, more clinical trials with a large sample and long-term follow-ups are needed for pragmatic use of these medicines, and further investigations on mechanisms will continue to deepen the understanding of these diseases and also accelerate the discovery of ideal treatment.

Keywords: ethanol, movement disorder, GABA receptor, low-voltage-activated calcium channel, glutamate receptor

\section{INTRODUCTION}

Ethanol is known to have a significant influence on human bodies, especially on the nervous system (1). Despite those negative effects as described in various studies, patients with certain diseases benefited from the consumption of ethanol. The clinical manifestation of ethanol-responsive movement disorders (ERMDs) could be significantly improved after ethanol intake. Patients with essential tremor (ET), one of the most common movement disorders influencing $\sim 1 \%$ of the population worldwide (2), were first reported to respond to ethanol in 1949 by Critchley (3). Similarly, alcohol intake has long been known to decrease myoclonic symptoms in most myoclonus dystonia (MD) patients since 1967 (4). Besides, cases of different phenotypes of dystonia 
(5-7), dyssynergia cerebellaris myoclonica (8-11), epilepsia partialis continua (12), post-hypoxic myoclonus (13), and tremor with multiple sclerosis (14) are also reported to have similar positive responses to ethanol (Table 1).

In spite of the differences in phenomenology of all these diseases mentioned above, their responsiveness to ethanol sets them apart from other movement disorders and brings up the possibility that the pathogenesis of these conditions might be linked to shared anatomical networks and the sensitivity to ethanol might be attributed to related mechanisms. Though not yet explored thoroughly, some hypotheses have already been raised to explain the phenomenon, mostly involving the GABA system, low-voltage-activated calcium channels, and glutamate pathways. Nevertheless, further investigations are needed to elucidate the pathophysiology.

Ethanol therapy has been already applied to some ethanolresponsive diseases such as essential tremor with clinical results. However, the therapeutic use of ethanol is limited by side effects involving the liver and brain and a high rate of alcoholism (22). Therefore, with deeper understanding of the pathogenesis, corresponding medicines have emerged subsequently to mimic alcohol-like effects through the common pathways among ERMDs.

In this review, we will elaborate reported diseases with ethanol responsiveness and analyze their shared anatomical networks, summarize the possible mechanisms underlying the treatment-like effects of ethanol, describe the main deficiencies of current ethanol therapy, and then introduce progress on relevant medication that could substitute for ethanol to avoid some of its side effects.

\section{ANATOMICAL NETWORKS INVOLVED IN RELEVANT DISEASES}

Ingestion of ethanol has long been proved to have a treatmentlike influence on hyperkinetic movement disorders (Table 1). While the therapeutic effects vary among different diseases, shared anatomical networks in these diseases, especially cerebellum and neural circuits related to the cerebellum, suggest the possibility of common mechanisms underlying ethanol responsiveness.

\section{Cerebellum and ERMDs}

As a sophisticated brain region that performs a wide range of crucial roles in movement disorders, the cerebellum integrates information from the spinal cord, cerebral cortex, and vestibular nuclei; compares efference copies and reafference signals; and corrects for discrepancies between them to enable the execution of smooth, well-coordinated movements. Undoubtedly, evidence from most published studies indicates the critical role of the cerebellum in the pathophysiology of ERMDs.

Essential tremor (ET), the most common movement disorder worldwide (2), is predominantly related to the cerebellum and is mainly linked to Purkinje cells, the main cerebellar output, and

TABLE 1 | Effects of ethanol on reported ethanol-responsive movement disorders.

\begin{tabular}{|c|c|c|c|c|c|c|c|}
\hline Diseases & $\begin{array}{l}\text { Year of first } \\
\text { report }\end{array}$ & $\begin{array}{l}\text { Proportion } \\
\text { of ethanol } \\
\text { responders }\end{array}$ & $\begin{array}{c}\text { Number of } \\
\text { reported } \\
\text { cases }\end{array}$ & $\begin{array}{l}\text { Administration } \\
\text { route }\end{array}$ & $\begin{array}{l}\text { Effective } \\
\text { dose }\end{array}$ & Clinical effects & References \\
\hline \multicolumn{8}{|l|}{ Tremor } \\
\hline Essential tremor & 1949 & $74 \%$ & - & $\begin{array}{l}\text { Intra- } \\
\text { arterial/Oral }\end{array}$ & Small dose & $\begin{array}{l}\text { Decrease tremor amplitude; } \\
\text { reduce gait disturbances }\end{array}$ & $(3,15-17)$ \\
\hline $\begin{array}{l}\text { Tremor with multiple } \\
\text { sclerosis }\end{array}$ & 2008 & - & 1 & Oral & - & Decrease tremor amplitude & (14) \\
\hline \multicolumn{8}{|l|}{ Myoclonus } \\
\hline Myoclonus dystonia & 1967 & $77 \%$ & - & Oral & - & $\begin{array}{l}\text { Reduce myoclonic symptoms; } \\
\text { improve cerebellar learning deficit }\end{array}$ & $(4,18,19)$ \\
\hline $\begin{array}{l}\text { Dyssynergia } \\
\text { cerebellaris myoclonica }\end{array}$ & 1990 & - & 12 & Oral & $\begin{array}{l}\text { 30-40 } \\
\text { g/180-200 ml } \\
\text { spirit }\end{array}$ & $\begin{array}{l}\text { Reduce myoclonic symptoms; } \\
\text { attenuate the giant cortical SEPs }\end{array}$ & $(8-11)$ \\
\hline $\begin{array}{l}\text { Post-hypoxic } \\
\text { myoclonus }\end{array}$ & 1991 & - & & Oral & $12.6 \mathrm{~g}$ & Reduce myoclonic symptoms & (13) \\
\hline $\begin{array}{l}\text { Epilepsia partialis } \\
\text { continua }\end{array}$ & 2014 & - & 1 & Oral & - & Reduce myoclonic symptoms & (12) \\
\hline $\begin{array}{l}\text { Action myoclonus in } \\
\text { prostate cancer }\end{array}$ & 2015 & - & 2 & Oral & Small dose & Reduce myoclonic symptoms & (20) \\
\hline Dystonia & & $29 \%$ & & & & & (21) \\
\hline Isolated dystonia & 1993 & - & 1 & Oral & $60 \mathrm{~g}$ & $\begin{array}{l}\text { Reduce myoclonic symptoms; } \\
\text { improve myorrhythmic } \\
\text { movements }\end{array}$ & (5) \\
\hline Spasmodic dysphonia & 2015 & $56 \%$ & - & Oral & 2 drinks & Reduce myoclonic symptoms & (6) \\
\hline Writer's cramp & 2012 & - & 1 & Oral & $200 \mathrm{ml}$ beer & Reduce myoclonic symptoms & (7) \\
\hline
\end{tabular}


the inhibitory neurons in the cerebellar cortex (23). Decreased density $(24,25)$, increased heterotopic rates (26), morphological changes on dendritic arborizations (27), and axonal changes (28) of Purkinje cells could be referred to hyperactivity of the cerebellum and consequently to tremor. Besides, neuroimaging studies, as a non-invasive approach of research, have also highlighted the morphologic abnormalities in the cerebellum. Atrophic changes in different lobules of the cerebellum, including gray matter and white matter, are revealed in previous studies $(29,30)$.

Myoclonus-dystonia being the second common disease in ERMDs, $\sim 76.9 \%$ of reported patients of myoclonus-dystonia (MD) were responsive to ethanol (31). Besides myoclonic symptoms, cerebellar learning deficits could also get improved via ethanol intake since reduced baseline acquisition of conditioned eyeblink responses and normal blink reflex recovery cycle were observed in MD patients after drinking (19), providing clinical evidence for the possible role of the cerebellum. Neurophysiological (32), structural (33), functional (34), and metabolic (35) studies also support the cerebellum as the subcortical generator underlying motor symptoms in MD. Moreover, impaired motor learning and abnormal nuclear envelope in the cerebellar Purkinje cells were detected in MD mouse models, the paternally inherited Sgce heterozygous knockout mice (36), and acute cerebellar knockdown of Sgce could reproduce salient features of MD in mice (37), further confirming the essential role of cerebellum in this disease.

As for dystonia, animal studies have also provided compelling evidence of a role played by the cerebellum in generating dystonic-like movements and postures, including altered burst patterns in Purkinje cell firing $(38,39)$, dysfunctional interactions with basal ganglia, another essential region for dystonia (40), and abnormal morphology of Purkinje cells (41). Studies on clinical patients with dystonia have provided neuropathologic (42), neurophysiologic, and functional neuroimaging evidence (43) for the significance of the cerebellum in dystonia.

In addition, though not compelling enough, other ERMDs are also likely linked to the cerebellum, revealed by different aspects of studies. For example, Ganos et al. (44) proposed that the cerebellum also played a critical role in the pathophysiology of cortical myoclonus including dyssynergia cerebellaris myoclonica (DCM) based on alterations in inhibitory neurotransmission and the presence of cerebellar pathology.

Overall, there is little doubt about the relationship between the cerebellum and ERMDs, and it is more and more likely that neural circuits and pathophysiological mechanisms involving the cerebellum are of great significance for these diseases.

\section{Cerebellum-Related Networks in ERMDs Cerebello-thalamo-Cortico-Cerebellar Loop}

Notably, given the dearth of direct connections between the cerebellum and peripheral nervous system, the intricate task of the cerebellum is mainly accomplished by modulating the excitability of the primary motor cortex through the cerebellothalamo-cortical tract. The altered cerebello-thalamo-corticocerebellar loop could be detected in different ERMDs.
Electrophysiology, structural magnetic resonance imaging (MRI), diffusion MRI, and positron emission tomography (PET) studies have revealed various abnormalities in cerebello-thalamocortico-cerebellar circuits in ET $(45,46)$. Based on that, a recent study revealed the distinctive white matter microstructural values localize to the cerebellar peduncles and thalamo-cortical visual pathways via diffusion tensor imaging (DTI) and fractional anisotropy, suggesting that a cerebello-thalamo (posterior) cortical network rather than a cerebello-thalamo-motor cortical network takes part in ET (47).

Functional MRI (fMRI) was performed using a validated "Go/No go" task to assess the possible network causing MD and demonstrated a distinct association of motor symptoms in MD with the cerebello-thalamo-cortical system (48). A study with voxel-based morphometry and DTI also illustrated the white matter changes found in the subthalamic area of the brain stem, connecting the cerebellum with the thalamus, which are compatible with the hypothesis that abnormal function in $\mathrm{MD}$ involves cerebello-thalamo-cortical pathways. Moreover, an altered cerebello-thalamo-cortico-cerebellar loop was revealed in other phenotypes of dystonia including MD through functional imaging (49) and neurophysiologic studies $(50,51)$.

In addition, abnormalities of key structures within the cerebello-thalamic-cortico-cerebellar loop were unveiled in some other ERMDs, despite lack of evidence of functional connectivity. Degeneration of cerebellar and thalamic regions was the pathological substrates for tremor in multiple sclerosis patients, implicated by a study based on structural MRI (52). Decrease in amplitude of giant cortical somatosensory-evoked potentials (SEPs) was confirmed in patients with DCM after alcohol ingestion (10), indicating the possible role of the cerebral cortex. Further studies based on neuroimaging and electrophysiology are needed to elucidate the connection between these regions.

\section{Guillain-Mollaret Triangle}

The Guillain-Mollaret triangle means the loop from the dentate nucleus to the red nucleus to inferior olivary (IO) nucleus to the dentate nucleus via the cerebellar cortex, which also participates in the pathogenesis of ERMDs such as ET and MD.

IO neurons have a natural tendency to oscillate in a synchronous pattern at a frequency of $4-10 \mathrm{~Hz}$, which is exactly the most common frequency seen in ET patients (53). Boecker et al. (54) once used $\mathrm{H}_{2}^{15} \mathrm{O}$ PET to investigate the effect of ethyl alcohol on regional cerebellar blood flow in patients with alcoholresponsive ET and found that alcohol suppressed cerebellar activities in both control and ET patients but induced increasing activities in IO only in the latter group. Animal models are also useful to interrogate the pathogenesis of the diseases. Harmaline is most frequently used to induce tremor in experimental models. It can induce ET-like tremor through its actions on the IO nuclei. Like tremor in ET patients, harmaline-induced tremor could be suppressed by ethanol (55). Besides, studies of diffusion tensor image (DTI) indicated the involvement of the superior cerebellar peduncle fiber tracts in ET patients, which receive input from the dentate nucleus and send output to the red nucleus (56). Based 
on these findings, a disturbance in the Guillain-Mollaret triangle may underlie tremor pathogenesis in ET.

As for MD patients, besides the involvement of the cerebellothalamo-cortico-cerebellar pathway, increased white matter volume and fractional anisotropy and decreased mean diffusivity were also found in the subthalamic area of the brain stem, including the red nucleus (33), also indicating the possible role of Guillain-Mollaret triangle.

\section{PATHOPHYSIOLOGIC MECHANISMS}

Since the discovery of ethanol responsiveness, researchers have never stopped investigating the pathophysiologic mechanisms underlying the phenomena. However, the specific mechanisms have not yet been fully elucidated. As mentioned above, ERMDs share common anatomical networks such as cerebellum and cerebellum-related circuits, which means the therapeutic effects of ethanol are largely attributed to similar pathways that play a critical role in these regions. Ethanol responsiveness might be the result of the combination of some of these known mechanisms or some other unknown pathways.

\section{GABA Pathways and ERMDs}

As the main inhibitory system in the nervous system, especially in cerebellum-related circuits, the reduction of GABAergic inhibitory function contributes to various ERMDs, such as ET, MD, progressive myoclonic epilepsy (44), and dystonia (57). Thus, GABA pathways were first linked to ethanol responsiveness, in which $\mathrm{GABA}$ receptors, including $\mathrm{GABA}_{\mathrm{A}}$ receptors and $\mathrm{GABA}_{\mathrm{B}}$ receptors, play a critical role.

\section{GABA $_{A}$ Receptors and ERMDs}

$\mathrm{GABA}_{\mathrm{A}}$ receptors $\left(\mathrm{GABA}_{\mathrm{A}} \mathrm{Rs}\right)$ are one of ligand-gated chloride channels. According to distribution, these receptors are divided into three types: postsynaptic $\mathrm{GABA}_{\mathrm{A}} \mathrm{R}$ containing $2 \alpha 1 / \alpha 2 / \alpha 3$ subunits, $2 \beta$ subunits, and $1 \gamma 2$ subunit that respond to benzodiazepine but not to ethanol; extra-synaptic expressed $\mathrm{GABA}_{\mathrm{A}} \mathrm{R}$ which contains $2 \alpha 4 / \alpha 6$ subunits, $2 \beta$ subunits, and $1 \delta$ subunit that respond to ethanol, general anesthetics, and neurosteroids rather than benzodiazepine $(58,59)$; and presynaptic $\mathrm{GABA}_{\mathrm{A}}$ Rs located on parallel fibers which could depolarize terminals to induce glutamate release onto molecular layer interneurons and Purkinje cells and thereby lead to increased excitability of target neurons (60) (Figure 1).

The connection between $\mathrm{GABA}_{\mathrm{A}} \mathrm{R}$ and ERMDs is controversial. Postsynaptic $\mathrm{GABA}_{\mathrm{A}} \mathrm{Rs}$ are first considered as a candidate participant in the pathogenesis of essential tremor (ET). Not only $\alpha 1$ subunit-deficient mice manifest with similar postural and kinetic tremor to ET (61), but PET studies (62) and autoradiography experiments (63) also supported altered postsynaptic $\mathrm{GABA}_{\mathrm{A}} \mathrm{R}$ functions among ET patients. However, the inconsistency in manifestations between $\alpha 1^{-/-}$ mice and ET patients casts doubt in this assumption. Specifically, tremor in $\alpha 1^{-/-}$mice presents earlier in life and has a higher mean frequency $(19.3 \mathrm{~Hz})$, accompanied by considerable incoordination, which is not typical for ET patients (61). Besides, there is no report about any association between homozygous $\alpha 1$ subunit mutations and patients with ET or other ERMDs, shedding the possibility that loss-of-function of $\alpha 1$ subunits only share part of mechanisms with ET pathogenesis.

Based on that, we try to explain it in three different angles. (1) Postsynaptic $\mathrm{GABA}_{\mathrm{A}} \mathrm{R}$ alterations are only restricted to one or certain parts of oscillation circuitry in ERMDs. For example, defective $\mathrm{GABA}_{\mathrm{A}} \mathrm{R}$ were detected in the dentate nucleus rather than the cerebellar cortex in patients with ET (64). (2) Presynaptic rather than postsynaptic $\mathrm{GABA}_{\mathrm{A}}$ Rs play a major role in the pathogenesis. In fact, the in vivo PET study of ET patients reveals increased benzodiazepine antagonist [11C]flumazenil signals (62) while ex vivo autoradiography experiments found decreased benzodiazepine binding (63). (3) Extra-synaptic GABAARs, which do not contain $\alpha 1$ subunits, also contribute to the mechanisms. Besides, $\alpha 1^{-/-}$mice, $\delta^{-/-}$, and $\alpha 6^{-/-}$mice also exhibited similar tremor to ET, and their symptoms were significantly improved after injection of inhibitors of extra-synaptic $\mathrm{GABA}_{\mathrm{A}}$ receptors (65) (Figure 2).

Ethanol is one of the activators of $\delta$ subunits of extrasynaptic $\mathrm{GABA}_{\mathrm{A}}$ receptors $(66,67)$. Tonic inhibition via extrasynaptic $\mathrm{GABA}_{\mathrm{A}}$ receptors is critical for long-term maintenance of the inhibitory status of neurons. Thus, ethanol might enhance tonic inhibition of target cells to compensate for dysfunction of postsynaptic or presynaptic $\mathrm{GABA}_{\mathrm{A}} \mathrm{Rs}$ and thereby relieve symptoms in ERMDs (Figure 3).

\section{GABA $_{B}$ Receptors and ERMDs}

$\mathrm{GABA}_{\mathrm{B}}$ receptors $\left(\mathrm{GABA}_{\mathrm{B}} \mathrm{Rs}\right)$, belonging to $\mathrm{G}$ protein-coupled receptors, perform different functions according to their location. When located presynaptically, activated $\mathrm{GABA}_{\mathrm{B}} \mathrm{Rs}$ prevent the release of neurotransmitters like GABA and glutamate. Postsynaptic $\mathrm{GABA}_{B} \mathrm{Rs}$, however, could induce hyperpolarization and slow inhibitory postsynaptic potentials (IPSP) and suppress glutamate receptors as well. Still, some $\mathrm{GABA}_{\mathrm{B}} \mathrm{Rs}$ exist extra-synaptically to inhibit T-type calcium channels, which will be further elaborated later (68) (Figure 1). The relationship between $G_{A B A} R$ and ERMDs is unclear, although abnormality of $\mathrm{GABA}_{\mathrm{B}} \mathrm{R}$ was detected in the dentate nucleus of ET patients (64) (Figure 2). Ethanol, as an activator for presynaptic $\mathrm{GABA}_{\mathrm{B}}$ receptors, is able to inhibit the release of glutamate and thereby suppress the excitability of postsynaptic cells (69), which help alleviate hyperkinetic symptoms of ERMDs (Figure 3).

\section{Low-Voltage-Activated Calcium Channels and ERMD}

Low-voltage-activated (LVA) calcium (Ca) channels, known as Ttype $\mathrm{Ca}^{2+}$ channels, belong to voltage-gated $\mathrm{Ca}^{2+}$ channels with high-voltage-activated (HVA) $\mathrm{Ca}^{2+}$ channels and intermediatevoltage-activated (IVA) $\mathrm{Ca}^{2+}$ channels. They are activated by $\mathrm{G}$ protein-coupled receptors such as $\mathrm{GABA}_{\mathrm{B}} \mathrm{Rs}$. Normally, the opening of HVA $\mathrm{Ca}^{2+}$ channels needs a large membrane depolarization, while a weak depolarization near the resting membrane potential could trigger the LVA Ca ${ }^{2+}$ channels, with IVA in between. Part of LVA $\mathrm{Ca}^{2+}$ channels stay inactivated under normal circumstances (70) (Figure 1). 


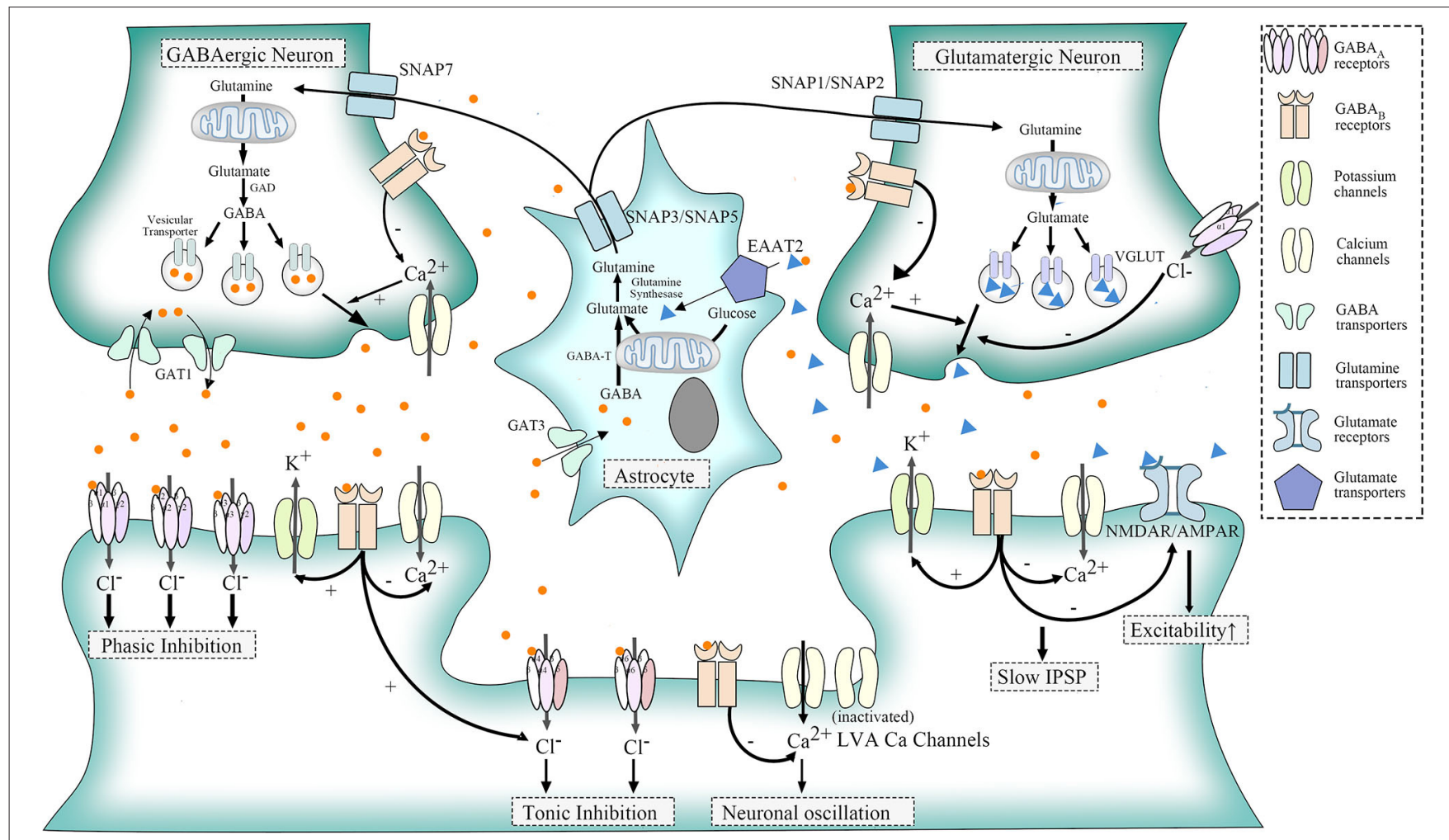

FIGURE 1 | Physiologic functions of GABA receptors, LVA Ca ${ }^{2+}$ channels, and glutamatergic pathways. GABA, transformed from glutamate in GABAergic neurons, acts through the combination of specific receptors. $\mathrm{GABA}_{A}$ receptors belong to ligand-gated chloride (Cl-) channels. Postsynaptic GABAA receptor, a mediator for phasic inhibition, consists of two $\alpha(\alpha 1-\alpha 3)$ subunits, two $\beta$ subunits, and one $\gamma 2$ subunit. The extra-synaptic GABA $A_{A}$ receptor, however, elicits tonic inhibition, containing two $\alpha(\alpha 4, \alpha 6)$ subunits, two $\beta$ subunits, and one $\delta$ subunit. GABA receptors could be distributed in three different sites. When located presynaptically, they could regulate the release of neurotransmitters of GABAergic and glutamatergic neurons via the suppression of HVA calcium channels. As for postsynaptic $G_{A B A}$ receptors, they could induce slow IPSP by activating outward potassium channels and suppressing inward HVA calcium channels. They also inhibit NMDAR/AMPAR to counteract the excitatory influence of glutamate. Besides, extra-synaptic GABA $A_{B}$ receptors, as well as other $G$ protein-coupled receptors, could activate LVA Ca channels to induce neuronal oscillation, though part of LVA calcium channels normally remain silent. With regard to glutamine, which could be transported into GABAergic neurons and glutamatergic neurons via SNAP7 and SNAP1/SNAP2, respectively, are the basic materials for synthesis of glutamate. In addition, astrocytes could uptake GABA through GABA transporter 3 (GAT3) and glutamate via EAAT2. Both glutamate and GABA could change into glutamine in astrocytes, and glutamine will be released to the intercellular space again through SNAP3/SNAP5.

LVA $\mathrm{Ca}^{2+}$ channels are confirmed to be associated with controlling neuronal excitability and oscillatory behavior, and an increasing number of studies have proved its relation with repetitive burst discharges. Genetically, the HS1BP3 gene, which encodes HS1-binding protein 3, is one of candidate genes for familial essential tremor (71) and highly expressed in motor neurons and Purkinje cells regulating $\mathrm{Ca}^{2+}$-dependent protein kinase activation of tyrosine and tryptophan hydroxylase (72). As for animal experiments, lack of $4-10 \mathrm{~Hz}$ rhythmic burst discharges in inferior olive (IO), a crucial promoter for essential tremor, was present in mice lacking the $\mathrm{Ca}_{V} 3.1$ gene (73), and five T-type calcium antagonists, including ethosuximide and zonisamide, suppressed tremor in two different animal tremor models (74), suggesting that LVA $\mathrm{Ca}^{2+}$ channels are the molecular pacemaker substrates for intrinsic neuronal oscillations of IO neurons, and this mechanism is likely to be a pathological cause of essential tremor (Figure 2).

Acute ethanol administration has been shown to cause disruption of native T-currents, and long-term disruption of LVA
$\mathrm{Ca}^{2+}$ channel expression and function occurs upon withdrawal after chronic intermittent ethanol exposures $(75,76)$. Ethanol inhibition of LVA $\mathrm{Ca}^{2+}$ channels is due to activation of the protein kinase $\mathrm{C}$ pathway, with a major effect on the hyperpolarized shift in inactivation (Figure 3). Among three isoforms of T-type $\mathrm{Ca}^{2+}$ channels $\left(\mathrm{Ca}_{\mathrm{v}} 3.1, \mathrm{Ca}_{\mathrm{v}} 3.2, \mathrm{Ca}_{\mathrm{V}} 3.3\right)$, $\mathrm{Ca}_{V} 3.2$ was significantly affected by ethanol, and might be another novel target for ethanol (77).

\section{Glutamate Pathways and ERMDs}

Impairment of glutamate pathways, especially different glutamatergic receptors, contributes to the onset of ERMDs such as ET and MD (78). One candidate alternation is the glutamate transporter mainly located in astrocytes, excitatory amino acid transporter 2 (EAAT2). These receptors uptake glutamate into astrocytes to regulate the concentration of glutamate in the extracellular space (Figure 1). Involvement of EAAT2 is supported by postmortem and ex vivo experimental studies that revealed decreased EAAT2 in the cerebellar cortex 


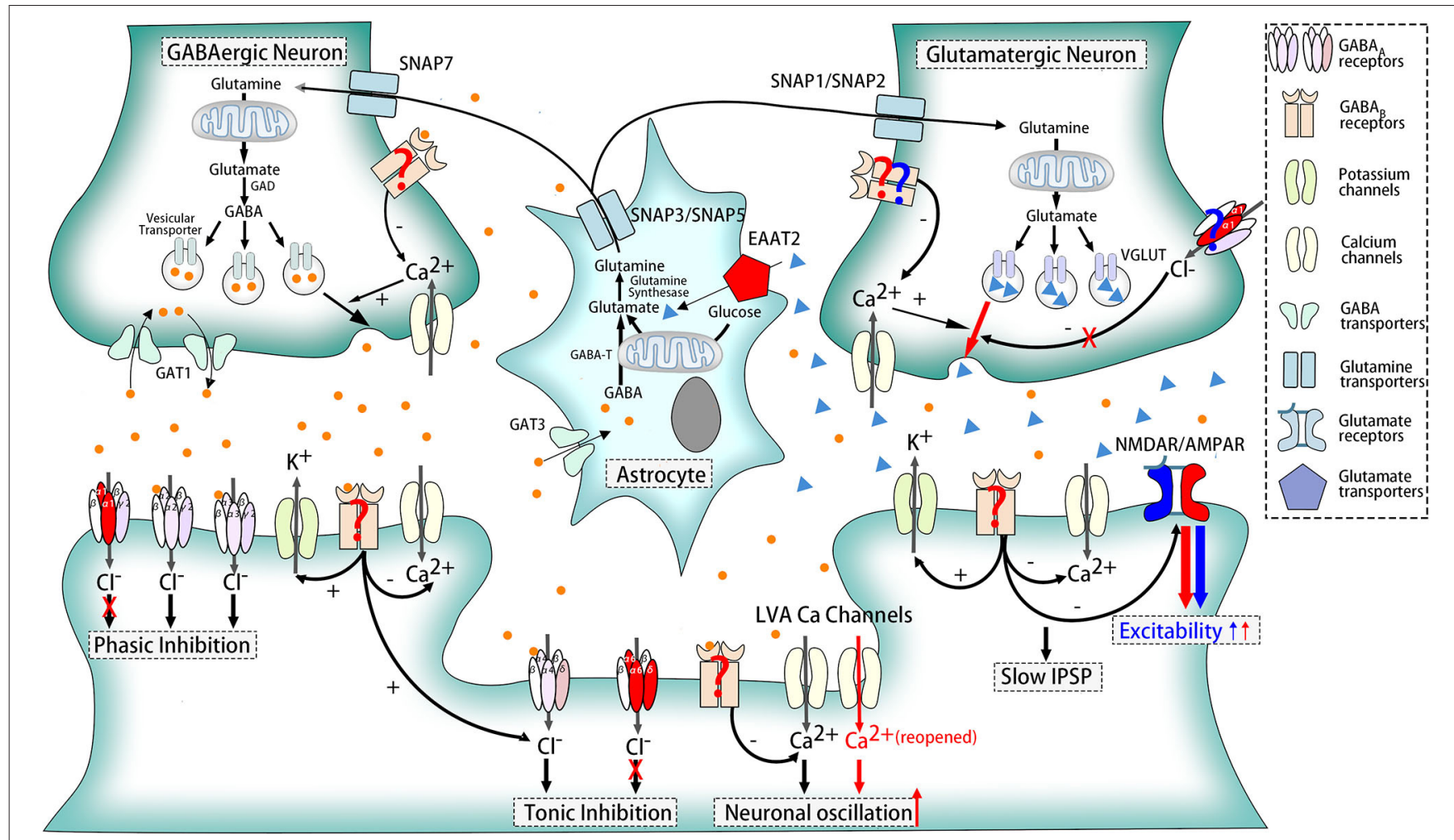

FIGURE 2 | Pathophysiologic mechanisms of ethanol-responsive movement disorders. Dysfunction of receptors and transporters marked in red participates in the pathogenesis of essential tremor, including $\alpha 1, \delta$, and $\alpha 6$ subunits of GABA $\mathrm{Rs}$, EAAT2, reopened LVA Ca ${ }^{2+}$ channels, and AMPAR. GABA $\mathrm{C}_{B}$ are also the potent participants, which was indicated in red question marks. Besides, compositions marked in blue contribute to myoclonus dystonia such as NMDAR and AMPAR. $\mathrm{GABA}_{\mathrm{A}} \mathrm{Rs}$ and $\mathrm{GABA} \mathrm{B}_{\mathrm{B}} \mathrm{Rs}$ in glutamatergic neurons are also likely to play a role in MD, shown in blue question marks as well.

and increased expression in the thalamus $(79,80)$ in patients with ET. In the genetic aspect, one variant (rs3794087) of the SLC1A2 gene encoding EAAT2 seems to be related with essential tremor $(81,82)$, though some other studies doubted this association (83-85). N-Methyl-D-aspartate receptor (NMDAR), a postsynaptic glutamate receptor and a regulator of efflux of $\mathrm{N}$-acetylaspartate (NAA) (86), is another possible participant in pathogenesis. Decreased NAA/creatine and NAA/choline ratios in the cerebellum, although no difference was observed in thalamus (80) or basal ganglia (87), backed up this view. In addition, another postsynaptic and extra-synaptic glutamate receptor, $\alpha$-amino-3-hydroxy-5-methyl-4-isoxazolepropionic acid receptor (AMPAR), also plays a significant role, supported by success suppression by AMPAR antagonist of harmalineinduced tremor, one of classic animal models for ET (88) (Figure 2).

Moreover, glutamate pathways are closely associated with GABA systems so that alterations in GABA receptors will also have significant influence on glutamate transmission. Glutamine, which could be transported into GABAergic neurons and glutamatergic neurons via system $\mathrm{N}$ receptors, SNAP7 and SNAP1/SNAP2, respectively, are the basic material to the synthesis of glutamate. GABA, subsequently, could be transformed into GABA in GABAergic neurons. To maintain a balance concentration in the intercellular space, astrocytes then take the responsibility to uptake GABA through GABA transporter 3 (GAT3) and glutamate via EAAT2. Both glutamate and GABA could change into glutamine again in astrocytes, and glutamine will be released to the intercellular space again through another two system $N$ receptors SNAP3/SNAP5. In addition, presynaptic and postsynaptic GABA receptors in glutamatergic synapses could inhibit the release of glutamate when activated (Figure 1). Impairment of this relation is a potential mechanism for MD. MD is often caused by mutations in the SGCE gene (89). SGCE encodes $\varepsilon$-sarcoglycan ( $\varepsilon$-SG) and a brain-specific isoform, expressed in GABA postsynaptic and presynaptic cells, respectively, and loss-of-function mutations are only found in those parts related to $\varepsilon-S G(90)$. Meanwhile, long-term depression of glutamatergic synapses was shown to be inhibited in a myoclonus dystonia mouse model (78). Therefore, dysfunction of postsynaptic GABA receptors might result in the pathogenesis of MD (Figure 2).

Ethanol is able to antagonize the effect of harmaline through impairment of NMDA-mediated glutamate transmission (91). Downregulation of EAAT2 and AMPAR (92) among chronic alcohol assumption also suggests their possible role for ethanol responsiveness (Figure 3), but more studies are in need for confirm their functions. 


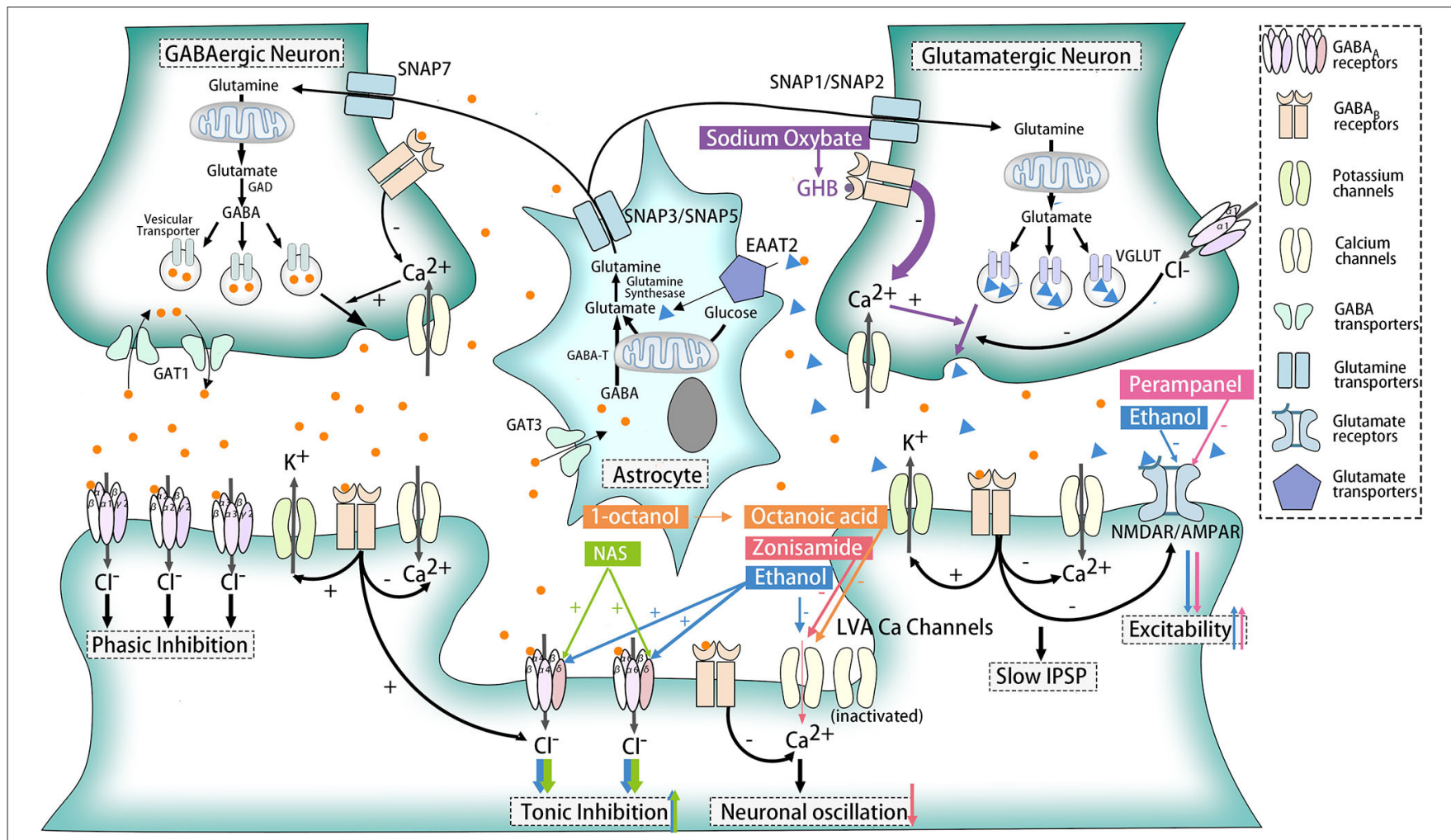

FIGURE 3 | Effects of ethanol and other medicines on ethanol-responsive movement disorders. The action sites of ethanol, sodium oxybate, NAS, zonisamide, perampanel, 1-octanol, and octanoic acid are marked with blue, purple, green, red, pink, and orange, respectively. Ethanol serves as an activator for the $\delta$ subunit of $\mathrm{GABA}_{A} \mathrm{Rs}$ and an inhibitor for LVA Ca ${ }^{2+}$ channels, NMDAR and AMPAR. Sodium oxybate could convert into GHB, a structural analog of GABA for GABA $\mathrm{B}_{\mathrm{B}}$ receptors. NAS is also the agonist of the $\delta$ subunit of GABA $A$ Rs, while zonisamide works as an antagonist for LVA Ca ${ }^{2+}$ channels. As for perampanel, it could suppress AMPAR selectively. Besides, 1-octanol and its active metabolite octanoic acid exhibited its ability to block LVA Ca ${ }^{2+}$ channels, but other mechanisms might participate at the same time.

\section{PROGRESS ON PHARMACOTHERAPY FOR ERMDS}

Though ethanol is able to alleviate symptoms of ERMDs to some degree, researchers gradually found that concomitant with improvements, the consumption of ethanol can also bring about a host of problems, regarding its efficacy, adverse effects, and misuse. First of all, ethanol is rapidly metabolized and eliminated in the human's body and exhibits a tendency to produce a rebound of involuntary movements when it wears off (22). These characteristics make it nearly impossible for ethanol to serve as long-term control or modulation of the frequency of paroxysms. Furthermore, the ameliorative effects of ethanol may lead to alcoholism especially in those symptomatic patients. As reported in most cases, ethanol of small doses could achieve the best therapeutic effects on patients of ethanol-responsive movement disorders. However, to maintain the same treatment effects, repeated doses are necessary and dose of ethanol increases over time (18). Therefore, alcoholism becomes a liability. Moreover, ethanol has various short-term and long-term adverse effects. With increasing frequency and rising doses due to tolerance, consumption of ethanol can cause irreversible damage to brains, livers, and other organs (93). Considering that some of ethanol-responsiveness diseases are characterized as early onset such as myoclonus dystonia, the damage once occurred may significantly affect patients' quality of life and life span.

Therefore, since ethanol is not a perfect treatment for patients of ethanol-responsive movement disorders, it is urgent to identify an alternative medication with fewer liabilities. Medicines that might meet the criteria are classified as follows (Table 2), and their potential therapeutic mechanisms are shown in the Figure 3. Treatment efficacy and deficiencies of these drugs are discussed.

\section{GABAergic Drugs}

There is a long history of the application of GABA modulators on ethanol-responsive movement disorders. Primidone, for instance, is the first-line therapy for ET which could reduce the amplitude of tremor by $70 \%$ (2). Patients with MD also received symptomatic improvements from benzodiazepine and primidone $(94,95)$. However, both drugs could bring up various irreversible adverse effects soon after regular intake, and longerterm survey reveals that approximately half of patients would discontinue consumption eventually due to tolerance or side effects. Such condition is possibly because of differences between the lesion locations and acting sites of these drugs. Recent 
TABLE 2 | Potential medicines for ethanol-responsive movement disorders.

\begin{tabular}{|c|c|c|c|c|c|c|}
\hline Drug name & Mechanisms & $t_{\max }$ & $t_{1 / 2}$ & Adverse effects & Effects on ERMDs & Clinical trials \\
\hline Sodium oxybate & $\mathrm{GABA}_{\mathrm{B}} \mathrm{R}$ agonist & $25-46 \min$ & $35-60 \mathrm{~min}$ & $\begin{array}{l}\text { Feeling drunk, } \\
\text { dizziness, headache, } \\
\text { abuse, respiratory } \\
\text { depression, seizures, } \\
\text { coma }\end{array}$ & $\begin{array}{l}\text { Improve myoclonic, } \\
\text { dystonia and tremor } \\
\text { symptoms, but with an } \\
60 \% \text { occurrence rate of } \\
\text { adverse events }\end{array}$ & $\begin{array}{l}\text { NCT03292458; } \\
\text { NCT00598078; } \\
\text { EUCTR2007-002222- } \\
\text { 30-FR }\end{array}$ \\
\hline SAGE-217 & $\begin{array}{l}\text { Extra-synaptic } \\
\text { GABAAR agonist }\end{array}$ & $1 \mathrm{~h}$ & $16-23 h$ & Sedation & $\begin{array}{l}\text { Well-tolerated and } \\
\text { achieve improvement } \\
\text { of tremor symptoms }\end{array}$ & NCT02978781 \\
\hline Zonisamide & $\begin{array}{l}\text { LVA Ca }{ }^{2+} \text { channel } \\
\text { blocker; GABA agonist }\end{array}$ & $2-6 h$ & $52-60 h$ & $\begin{array}{l}\text { Headache, nausea, } \\
\text { fatigue, sleepiness, and } \\
\text { diarrhea }\end{array}$ & $\begin{array}{l}\text { Well-tolerated and } \\
\text { improvement in ET, MD } \\
\text { and tardive dyskinesia }\end{array}$ & $\begin{array}{l}\text { NCT00616343; } \\
\text { NCT01806805 }\end{array}$ \\
\hline Perampanel & $\begin{array}{l}\text { Highly-selective, } \\
\text { non-competitive } \\
\text { AMPAR antagonist }\end{array}$ & $0.55-11 \mathrm{~h}$ & $64.9-129 h$ & $\begin{array}{l}\text { Dizziness, somnolence, } \\
\text { fatigue and headache }\end{array}$ & $\begin{array}{l}\text { Markedly exhibit } \\
\text { anti-tremor effects on } \\
\text { ET patients }\end{array}$ & NCT02668146 \\
\hline $\begin{array}{l}\text { 1-Octanol and octanoic } \\
\text { acid }\end{array}$ & $\begin{array}{l}\text { Unclear (could serve as } \\
\text { a LVA Ca }{ }^{2+} \text { channel } \\
\text { blocker) }\end{array}$ & 70 min* $^{\star}$ & $83.5 \mathrm{~min}^{*}$ & $\begin{array}{l}\text { Headache, asthenia, } \\
\text { lethargy, nausea, dry } \\
\text { mouth, taste change, } \\
\text { heartburn, bloating, } \\
\text { and constipation }\end{array}$ & $\begin{array}{l}\text { Well-tolerated and } \\
\text { receive remarkable } \\
\text { improvements on } \\
\text { amplitude and } \\
\text { frequency of tremor }\end{array}$ & $\begin{array}{l}\text { NCT00001986; } \\
\text { NCT00102596; } \\
\text { NCT00848172; } \\
\text { NCT01468948; } \\
\text { NCT01864525 }\end{array}$ \\
\hline
\end{tabular}

*1-Octanol is transformed into octanoic acid soon after administration. Here lists pharmacokinetics of octanoic acid.

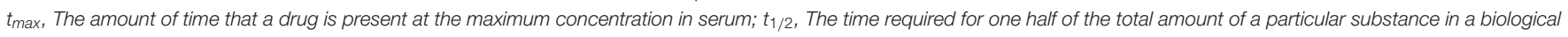
system to be degraded by biological processes when the rate of removal is nearly exponential.

clinical trials, as a result, focused more on relatively safe, efficient, concentric drugs. Here, newly experimental GABAergic drugs are exhibited.

\section{Sodium Oxybate}

Sodium oxybate is currently an approved medicine for narcolepsy in the United States and also used for intravenous anesthesia, ethanol withdrawal, and abstinence in Europe (96). It is the sodium salt form of $\gamma$-hydroxybutyric acid (GHB), a structural analog of $\mathrm{GABA}$ that interacts with $\mathrm{GABA}_{\mathrm{B}}$ receptors. When ingested orally, it could be quickly absorbed and cross the bloodbrain barrier, converted into GHB within the brain (97). It is proved to be an agonist of most $\mathrm{GABA}_{\mathrm{B}}$ receptors as well (98), which also suggests that it might deliver a similar effect to ethanol.

Recent clinical trials showed that over half of patients with ethanol-responsive movement disorders achieved symptom improvement after administration of sodium oxybate, and the improvement of myoclonus at rest usually occurs earlier than that of myoclonus in action. In 2000, Priori et al. (99) reported a patient with ethanol-responsive MD whose myoclonus was improved with daytime dosing of sodium oxybate. Later on, patients with post-hypoxic myoclonus (96) and spasmodic dysphonia (100) (NCT03292458) were also reported to demonstrate dose-dependent improvements from sodium oxybate. In addition, Termsarasab and Frucht (20) reported that two patients of prostate cancer with ethanolresponsive action myoclonus of one leg went into remission after initiation of sodium oxybate.

However, a multiple-dose, double-blind, placebo-controlled study in ET patients (NCT00598078) did not receive an ideal result. Although the group using sodium oxybate $1.5 \mathrm{~g}$ at $\sim 8$ am, placebo at $\sim 10 \mathrm{am}$, and sodium oxybate $1.5 \mathrm{~g}$ at $\sim 12 \mathrm{pm}$ appeared to get improvement in essential rating tremor scales, safety problems cannot be ignored that $60 \%$ of group members met with adverse events during the studies. Currently, a singleand multiple-dose study to compare the pharmacokinetics, pharmacodynamics, safety, and tolerability of sodium oxybate in subjects with moderate to severe ET (EUCTR2007-002222-30FR) is under way, which might bring about a more convincing and comprehensive evaluation on this medicine.

Application of sodium oxybate is facing a number of problems. Firstly, the average time for sodium oxybate to peak plasma concentration ranges from 35 to $60 \mathrm{~min}$, and it is rapidly eliminated through several steps into carbon dioxide and water with a terminal half-life of $36 \pm 9 \mathrm{~min}$ for $25 \mathrm{mg} / \mathrm{kg}$ and $39 \pm$ $7 \mathrm{~min}$ for $35 \mathrm{mg} / \mathrm{kg}$ (101). This means sodium oxybate could only serve for temporary improvement rather than long-term control. In addition, the best effect of the drug was observed in patients who reported improvement of symptoms with small doses of alcohol. For those patients less sensitive to ethanol, they might get benefits from sodium oxybate with increased doses (100), but adverse effects such as dizziness, headache, abuse, respiratory depression, seizures, and coma, especially when taken with other central nervous system depressants like ethanol, will overshadow the ethanol-mimetic effects (102). These side effects will not only limit the practical use of sodium oxybate but also bring up safety issues.

In short, sodium oxybate has potential in improving symptoms of ethanol-responsive movement disorders temporarily and rapidly, especially for patients with high sensitivity to ethanol, but its safety is a concern.

\section{Neuroactive Steroids}

Neuroactive steroids (NASs) are one of positive modulators for the $\delta$ subunit of extra-synaptic $\mathrm{GABA}_{\mathrm{A}} \mathrm{Rs}$ as mentioned 
above (103). SAGE-547, the first-generation NAS, has completed an exploratory study in ET. Although well-tolerated, little evidence for increased efficacy was found during the openlabel period, and increased sedation and sleepiness at the higher dose questioned its safety for long-term treatment (104). Subsequently, SAGE-217, another NAS, is under clinical trials for ET. A phase 1 single ascending dose (SAD) and multiple ascending dose (MAD) clinical trial has completed and a phase 2 clinical trial (NCT02978781) is currently underway. Results of the phase 1 study showed that SAGE-217 was orally bioavailable, with a terminal-phase half-life of $16-23 \mathrm{~h}$ and a tmax of $\sim 1 \mathrm{~h}$. No serious adverse events were reported during both SAD and MAD studies, and mild adverse events including sedation were dose-dependent and transient. The primary results for phase 2 research indicated that SAGE-217 30-mg capsules were generally well-tolerated and achieve improvement of tremor symptoms via Kinesia $^{\mathrm{TM}}$ and TETRAS upper-limb combined kinetic and total scores (105). Detailed data is needed to fully assess the reliability and validity of this trials, and further randomized controlled trials (RCTs) should be carried out to fully explore the efficacy and safety of SAGE-217.

\section{LVA $\mathrm{Ca}^{2+}$ Channel Blockers}

Little data are available on the effects of LVA $\mathrm{Ca}^{2+}$ channel blockers on ERMDs. To date, among all the definite LVA $\mathrm{Ca}^{2+}$ channel blockers, only ethosuximide and zonisamide were reported to have effects on animal models $(74,106,107)$, but little clinical efficacy was found in ethosuximide (108). Here, progress on zonisamide is elaborated in clinical trials.

\section{Zonisamide}

Zonisamide is a medication mainly used to treat symptoms of epilepsy in the United States, United Kingdom, Japan, South Korea, and Australia with different application ranges and is also used in the treatment of motor symptoms of Parkinson's disease in some countries such as Japan (109). It has multiple mechanisms of action, including inhibition of sodium and T-type calcium channels, to suppress neuronal hypersynchronization (110) and modulation of GABAergic neurotransmission (111). Thus, zonisamide could mimic the influence of ethanol in different ways and is likely to replace ethanol for similar or even better results with fewer side effects.

Clinical evidence has demonstrated the potential of zonisamide for treatments of ethanol-responsive movement disorders. In 2008, Zesiewicz et al. (112) conducted a doubleblind placebo-controlled trial to investigate the effects of zonisamide in patients of essential tremor (NCT00616343) and found that tremor amplitude was significantly improved in the group with zonisamide intake, and $60 \%$ of patients of this group demonstrated improvements while the others felt that their tremor was at least "minimally improved." In 2012, Iwata et al. (113) discovered that zonisamide may be useful for the treatment of tardive dyskinesia, a disease reported to be responsive to ethanol. Patients of myoclonus dystonia also benefited from use of zonisamide (NCT01806805), with significant improvements in action myoclonus, myoclonus-related functional disability, and dystonia (114).
Zonisamide has a clear advantage over ethanol in that it has been proved relatively safe, effective, and well-tolerated in long-term treatments as monotherapy or adjunctive therapy $(115,116)$. Additionally, zonisamide has a pharmacokinetic characteristic favorable for clinical use. It is rapidly absorbed orally, with a bioavailability close to $100 \%$. The time to peak blood levels is achieved in about 2-6h (117), with the half-life of $52-60 \mathrm{~h}$ found in single-dose studies $(118,119)$. Therefore, zonisamide can be used in conjunction with ethanol or sodium oxybate that the former one serves as a long-term control; the latter two can work for temporary relief. Nevertheless, zonisamide is associated with some common adverse effects of this medicine, such as headache, nausea, fatigue, sleepiness, and diarrhea (117). These side effects will definitely impact the quality of life in patients, reduce compliance, and even cause irreversible damages. In addition, all the clinical trials we found were small in sample size and poor at blinding, which is insufficient for clinical applications. RCTs with adequate methodology and large samples should be performed to assess long-term efficacy and safety.

\section{Glutamate Receptor Blockers}

Although glutamatergic pathways are considered tightly associated with ERMDs, not much clinical trial has been done on corresponding drugs. Here we introduce one potent blocker for glutamate receptors.

\section{Perampanel}

Perampanel, approved as an antiepileptic drug currently, is a highly selective, non-competitive AMPAR antagonist that could regulate glutamate neurotransmission. Perampanel was rapidly absorbed when taken orally, reaching its maximum concentration after $0.55-11 \mathrm{~h}$, and its terminal-phase half-life was $64.9-129 \mathrm{~h}$, indicating its rapid onset and long maintenance (120). The most common adverse effects for perampanel are dizziness, somnolence, fatigue, and headache (121). An openlabel trial of perampanel has completed for ET treatment (NCT02668146). In a small sample size of 12, perampanel exhibited marked anti-tremor effect (122). RCTs with large samples and long-term follow-up are still needed to confirm its effectiveness and safety.

\section{Long-Chain Alcohols and Their Ramifications}

Till now, it remains uncertain whether or not using one or some of the drugs mentioned above could completely mimic the effects of ethanol in all aspects, especially considering the uncertain involvement of those unknown mechanisms. Thus, other alcohols were expected to substitute ethanol in a better way. Alcohols ranging from methanol to decanol were all studied in vitro, in which octanol, unlike others, showed its ability to block LVA $\mathrm{Ca}^{2+}$ channels, and 1-octanol exhibited the best efficacy mainly due to its longer duration among all isoforms in models of essential tremor (123). Still, 1-octanol might act through other mechanisms like GABA-receptor interaction. 


\section{1-Octanol and Octanoic Acid}

1-Octanol is approved as a food flavoring substance and a precursor to perfumes. It is rapidly converted to octanoic acid after administration. Octanoic acid is then likely to work as active metabolite in the body, while the concentration of 1-octanol is maintained at a relevantly low level (124). In 1989, Sinton et al. (125) revealed that 1-octanol was an effective blocker of harmaline-induced tremor. Bushara et al. (126) then conducted a pilot trial of 1-octanol in ET patients (NCT00001986) and found that 1-octanol significantly decreased tremor amplitude for up to $90 \mathrm{~min}$ and no severe side effects or signs of intoxication were observed at a single oral dose of $1 \mathrm{mg} / \mathrm{kg}$. A dose-escalation study (NCT00102596) of oral 1-octanol in patients with essential tremor then demonstrated that 1-octanol was well-tolerated up to $64 \mathrm{mg} / \mathrm{kg}$ without overt intoxication, and higher doses may produce more sustained benefit (127).

Octanoic acid is also used as food and cosmetic additive and sometimes used in assessment of gastric emptying. It could permeate the blood-brain barrier in the rat by a rate of $94 \%$ (128). In 2012, a study in a harmaline-induced mouse model of ET showed that octanoic acid could suppress tremor following dose-dependent efficacy (129). To assess an oral, single, low dose of octanoic acid in patients with ethanol-responsive ET, Haubenberger et al. (130) conducted a randomized controlled study (NCT00848172) and reached a conclusion that octanoic acid was effective after $180 \mathrm{~min}$ of intake. Furthermore, Voller et al. (131) described the dose-dependent effect of octanoic acid in patients with essential tremor (NCT01468948); a single dose of $128 \mathrm{mg} / \mathrm{kg}$ was not associated with serious adverse events. Patients with essential voice tremor also received considerable improvement on magnitude of amplitude and frequency tremor (NCT01864525), further supporting the potential utility of octanoic acid for ERMDs (132).

One overt advantage of 1-octanol and octanoic acid is its safety. Based on the results of all the clinical trials so far, mild adverse effects include headache, asthenia, lethargy, nausea, dry mouth, taste change, heartburn, bloating, and constipation (130). Moreover, among all the research, the maximum tolerated doses of two drugs are still unknown, further highlighting their safety. In addition, 1-octanol and octanoic acid show a longer duration than ethanol. Octanoic acid, serving as one possible drug as well as being the primary metabolite of 1octanol, has a half-life time of $83.5 \mathrm{~min}$ (130). Nevertheless, the effects of long-chain alcohol and their ramifications on other ethanol-responsive movement disorders require additional experimental and clinical investigations. In other movement disorders, 1-octanol and octanoic acid may not show the best efficacy.

\section{LIMITATIONS}

The present understanding on the mechanisms and pharmacotherapy of ERMDs should be considered in the context of the following limitations.

In the aspects of neural networks involved in these diseases, though compelling evidence has supported the essential role of the cerebellum and circuits linked to the cerebellum, the unsolved question is whether these movement disorders are originated from the cerebellum, or are subsequently mediated by other structures within the shared anatomical networks, or are the result of disruption in connectivity between several brain structures. Future investigations on this question will be helpful for a better understanding of these diseases and development of optimal pharmacotherapy and neurosurgical intervention for ERMDs.

As for pathophysiologic mechanisms, the current hypothesis can only partly elucidate the effects of ethanol on ERMDs. It has been proved that genetic etiology is probably an indicator of ethanol responsiveness $(21,133)$. Early-onset ET has a higher possibility of a positive family history, and Hopfner et al. (133) compared patients under 24 years of age to those over 46 of ET and found that ethanol responsiveness was much more common among young patients. Junker et al. (21) recently concluded in a recent large sample research that ethanol responsiveness of dystonia is associated with a positive family history for movement disorders, generalized dystonia, and an earlier age at onset. These two studies suggest that patients who have an underlying genetic contribution are more likely to respond beneficially to ethanol. However, the genetic connection among GABA systems and ERMDs, though important, remains unclear. On the one hand, it suggests that during genetic analysis of ERMDs, genes related to GABA pathways need to be paid more attention to. On the other hand, based on discovered genetic risk factors, some new mechanisms might be uncovered for a better understanding and more effective therapy for ERMDs. In addition, some deficiencies, especially safety concerns, exist among alternative medicines mentioned above. Lack of large-sample, long-term clinical trials also make it insufficient for clinical application of these medicines. Therefore, developing a more effective and safer drug is key to further development of treatment for diseases responsive to ethanol, which is possibly inspired by deeper understanding of ethanol responsiveness.

\section{CONCLUSION}

Ethanol-responsive movement disorders are a group of dyskinesia, of which clinical manifestation could receive significant improvement after consumption of ethanol. Despite their various clinical features, these diseases share similar anatomical targets and common physiopathological sites for ethanol. Cerebellum and cerebellum-related neural circuits are the most potent common anatomical regions involved in ERMDs, in which GABA pathways, LVA $\mathrm{Ca}^{2+}$ channels, and glutamatergic system play key roles. Corresponding drugs have received clinical results with fewer liabilities compared to ethanol, including GABAergic drugs like sodium oxybate and NASs, LVA $\mathrm{Ca}^{2+}$ channel blockers like zonisamide, glutamate receptor antagonists like perampanel, and long-chain alcohols like 1-octanol and its corresponding acid. Promoting the use of these drugs may be a boon to patients, improving their quality of life and extending their lives. However, there is still a long way 
for clinical application of these drugs due to lack of large-sample, long-term follow-up data. Further exploration on neuro-circuits and mechanisms underlying ethanol responsiveness will also deepen the understanding of these diseases and accelerate the discovery of ideal treatment.

\section{AUTHOR CONTRIBUTIONS}

JW was the major contributor for manuscript writing. HT and SC contributed to manuscript critique and revision. LC was a

\section{REFERENCES}

1. de la Monte SM, Kril JJ. Human alcohol-related neuropathology. Acta Neuropathol. (2014) 127:71-90. doi: 10.1007/s00401-013-1233-3

2. Tuleasca C, Regis J, Levivier M. Essential Tremor. N Engl J Med. (2018) 379:595-6. doi: 10.1056/NEJMc1807690

3. Critchley M. Observations on essential (heredofamial) tremor. Brain. (1949) 72:113-39. doi: 10.1093/brain/72.2.113

4. Mahloudji M, Pikielny RT. Hereditary essential myoclonus. Brain. (1967) 90:669-74. doi: 10.1093/brain/90.3.669

5. Gudin M, Vaamonde J, Rodriguez M, Obeso JA. Alcohol sensitive dystonia. Mov Disord. (1993) 8:122-3. doi: 10.1002/mds.870080125

6. Kirke DN, Frucht SJ, Simonyan K. Alcohol responsiveness in laryngeal dystonia: a survey study. J Neurol. (2015) 262:154856. doi: 10.1007/s00415-015-7751-2

7. Lim SC, Kim JS, An JY, S. Yoon Kang: alcohol-responsive writer's cramp. Intern Med. (2012) 51:99-101. doi: 10.2169/internalmedicine.51.6322

8. Genton P, Guerrini R. Antimyoclonic effects of alcohol in progressive myoclonus epilepsy. Neurology. (1990) 40:14126. doi: 10.1212/WNL.40.9.1412

9. Jain S, Tamer SK, Hiran S. Beneficial effect of alcohol in hereditary cerebellar ataxia with myoclonus (progressive myoclonic ataxia): report of two siblings. Mov Disord. (1996) 11:751-2. doi: 10.1002/mds.870110629

10. Lu CS, Chu NS. Effects of alcohol on myoclonus and somatosensory evoked potentials in dyssynergia cerebellaris myoclonica. J Neurol Neurosurg Psychiatry. (1991) 54:905-8 doi: 10.1136/jnnp.54.10.905

11. Hsiao MC, Liu CY, Yang YY, Lu CS, Yeh EK. Progressive myoclonic epilepsies syndrome (Ramsay Hunt syndrome) with mental disorder: report of two cases. Psychiatry Clin Neurosci. (1999) 53:575-8. doi: 10.1046/j.1440-1819.1999.00608.x

12. Steve TA, Gross DW. Alcohol-responsive epilepsia partialis continua. Epileptic Disord. (2014) 16:107-11. doi: 10.1684/epd.2014.0626

13. Jain S, Jain M. Action myoclonus (Lance-Adam syndrome) secondary to strangulation with dramatic response to alcohol. Mov Disord. (1991) 6:183. doi: $10.1002 / \mathrm{mds} .870060219$

14. Hammond ER, Kerr DA. Ethanol responsive tremor in a patient with multiple sclerosis. Arch Neurol. (2008) 65:1423. doi: 10.1001/archneurol.2007.13

15. Hopfner F, Erhart T, Knudsen K, Lorenz D, Schneider SA, Zeuner KE, et al. Testing for alcohol sensitivity of tremor amplitude in a large cohort with essential tremor. Parkinsonism Relat Disord. (2015) 21:84851. doi: 10.1016/j.parkreldis.2015.05.005

16. Growdon JH, Shahani BT, Young RR. The effect of alcohol on essential tremor. Neurology. (1975) 25:259-62. doi: 10.1212/WNL.25.3.259

17. Klebe S, Stolze H, Grensing K, Volkmann J, Wenzelburger R, Deuschl G. Influence of alcohol on gait in patients with essential tremor. Neurology. (2005) 65:96-101. doi: 10.1212/01.wnl.0000167550.97413.1f

18. Hess CWR. Saunders-Pullman: movement disorders and alcohol misuse. Addict Biol. (2006) 11:117-25. doi: 10.1111/j.1369-1600.2006.00017.x

19. Weissbach A, Werner E, Bally JF, Tunc S, Lons S, Timmann D, et al. Alcohol improves cerebellar learning deficit in myoclonus-dystonia: a contributor in funding, manuscript critique, and revision. All authors read and approved the final manuscript.

\section{FUNDING}

This work was supported by grants from the National Natural Science Foundation of China (Nos. 81870889, 81571086), Shanghai Municipal Education CommissionGaofeng Clinical Medicine Grant Support (No. 20161401), and Interdisciplinary Project of Shanghai Jiao Tong University (No. YG2016MS64). clinical and electrophysiological investigation. Ann Neurol. (2017) 82:54353. doi: 10.1002/ana.25035

20. Termsarasab P, Frucht SJ. Alcohol-responsive action myoclonus of the leg in prostate cancer: a novel paraneoplastic syndrome? Tremor Other Hyperkinet Mov. (2015) 5:357. doi: 10.5334/tohm.261

21. Junker J, Brandt V, Berman BD, Vidailhet M, Roze E, Weissbach A, et al. Predictors of alcohol responsiveness in dystonia. Neurology. (2018) 91:e2020-6. doi: 10.1212/WNL.0000000000006551

22. Deik AR. Saunders-Pullman and Luciano MS. Substance of abuse and movement disorders: complex interactions and comorbidities. Curr Drug Abuse Rev. (2012) 5:243-53 doi: 10.2174/1874473711205030243

23. Louis ED. Essential tremor: evolving clinicopathological concepts in an era of intensive post-mortem enquiry. Lancet Neurol. (2010) 9:61322. doi: 10.1016/S1474-4422(10)70090-9

24. Choe M, Cortes E, Vonsattel JP, Kuo SH, Faust PL, Louis ED. Purkinje cell loss in essential tremor: random sampling quantification and nearest neighbor analysis. Mov Disord. (2016) 31:393-401. doi: 10.1002/mds.26490

25. Louis ED, Babij R, Lee M, Cortes E, Vonsattel JP. Quantification of cerebellar hemispheric purkinje cell linear density: $32 \mathrm{ET}$ cases versus 16 controls. Mov Disord. (2013) 28:1854-9. doi: 10.1002/mds.25629

26. Kuo SH, Erickson-Davis C, Gillman A, Faust PL, Vonsattel JP, Louis ED. Increased number of heterotopic Purkinje cells in essential tremor. J Neurol Neurosurg Psychiatry. (2011) 82:1038-40. doi: 10.1136/jnnp.2010.213330

27. Louis ED, Lee M, Babij R, Ma K, Cortes E, Vonsattel JP, et al. Reduced Purkinje cell dendritic arborization and loss of dendritic spines in essential tremor. Brain. (2014) 137:3142-8. doi: 10.1093/brain/awu314

28. Louis ED, Vonsattel JP, Honig LS, Ross GW, Lyons KE, Pahwa R. Neuropathologic findings in essential tremor. Neurology. (2006) 66:17569. doi: 10.1212/01.wnl.0000218162.80315.b9

29. Quattrone A, Cerasa A, Messina D, Nicoletti G, Hagberg GE, Lemieux L, et al. Essential head tremor is associated with cerebellar vermis atrophy: a volumetric and voxel-based morphometry MR imaging study. AJNR Am J Neuroradiol. (2008) 29:1692-7. doi: 10.3174/ajnr.A1190

30. Cerasa A, Messina D, Nicoletti G, Novellino F, Lanza P, Condino F, et al. Cerebellar atrophy in essential tremor using an automated segmentation method. AJNR Am J Neuroradiol. (2009) 30:1240-3. doi: 10.3174/ajnr.A1544

31. Hess CW, Raymond D, Aguiar Pde C, Frucht S, Shriberg J, Heiman GA, et al. Myoclonus-dystonia, obsessive-compulsive disorder, and alcohol dependence in SGCE mutation carriers. Neurology. (2007) 68:5224. doi: 10.1212/01.wnl.0000253188.76092.06

32. Marelli C, Canafoglia L, Zibordi F, Ciano C, Visani E, Zorzi G, et al. A neurophysiological study of myoclonus in patients with DYT11 myoclonusdystonia syndrome. Mov Disord. (2008) 23:2041-8. doi: 10.1002/mds. 22256

33. van der Meer JN, Beukers RJ, van der Salm SM, Caan MW, Tijssen MA, Nederveen AJ. White matter abnormalities in gene-positive myoclonusdystonia. Mov Disord. (2012) 27:1666-72. doi: 10.1002/mds.25128

34. Beukers RJ, Foncke EM, van der Meer JN, Veltman DJ, Tijssen MA. Functional magnetic resonance imaging evidence of incomplete maternal imprinting in myoclonus-dystonia. Arch Neurol. (2011) 68:8025. doi: 10.1001/archneurol.2011.23 
35. Carbon M, Raymond D, Ozelius L, Saunders-Pullman R, Frucht S, Dhawan $\mathrm{V}$, et al. Metabolic changes in DYT11 myoclonus-dystonia. Neurology. (2013) 80:385-91. doi: 10.1212/WNL.0b013e31827f0798

36. Yokoi F, Dang MT, Yang G, Li J, Doroodchi A, Zhou T, et al. Abnormal nuclear envelope in the cerebellar Purkinje cells and impaired motor learning in DYT11 myoclonus-dystonia mouse models. Behav Brain Res. (2012) 227:12-20. doi: 10.1016/j.bbr.2011.10.024

37. Washburn S, Fremont R, Moreno-Escobar MC, Angueyra C, Khodakhah K. Acute cerebellar knockdown of Sgce reproduces salient features of myoclonus-dystonia (DYT11) in mice. Elife. (2019) 8:e52101. doi: 10.7554/eLife.52101

38. Fremont R, Calderon DP, Maleki S, Khodakhah K. Abnormal high-frequency burst firing of cerebellar neurons in rapid-onset dystonia-parkinsonism. $J$ Neurosci. (2014) 34:11723-32. doi: 10.1523/JNEUROSCI.1409-14.2014

39. LeDoux MS, Hurst DC, Lorden JF. Single-unit activity of cerebellar nuclear cells in the awake genetically dystonic rat. Neuroscience. (1998) 86:53345. doi: 10.1016/S0306-4522(98)00007-4

40. Neychev VK, Fan X, Mitev VI, Hess EJ, Jinnah HA. The basal ganglia and cerebellum interact in the expression of dystonic movement. Brain. (2008) 131:2499-509. doi: 10.1093/brain/awn168

41. Zhang L, Yokoi F, Jin YH, DeAndrade MP, Hashimoto K, Standaert DG, et al. Altered dendritic morphology of Purkinje cells in Dyt1 DeltaGAG knockin and purkinje cell-specific Dytl conditional knockout mice. PLoS ONE. (2011) 6:e18357. doi: 10.1371/journal.pone.0018357

42. Batla A, Sanchez MC, Erro R, Ganos C, Stamelou M, Balint B, et al. The role of cerebellum in patients with late onset cervical/segmental dystonia?evidence from the clinic. Parkinsonism Relat Disord. (2015) 21:131722. doi: 10.1016/j.parkreldis.2015.09.013

43. Bologna M, Berardelli A. The cerebellum and dystonia. Handb Clin Neurol. (2018) 155:259-72. doi: 10.1016/B978-0-444-64189-2.00017-2

44. Ganos C, Kassavetis P, Erro R, Edwards MJ, Rothwell J, Bhatia KP. The role of the cerebellum in the pathogenesis of cortical myoclonus. Mov Disord. (2014) 29:437-43. doi: 10.1002/mds. 25867

45. Klaming R, Annese J. Functional anatomy of essential tremor: lessons from neuroimaging. AJNR Am J Neuroradiol. (2014) 35:1450-7. doi: 10.3174/ajnr.A3586

46. Muthuraman M, Raethjen J, Koirala N, Anwar AR, Mideksa KG, Elble R, et al. Cerebello-cortical network fingerprints differ between essential, Parkinson's and mimicked tremors. Brain. (2018) 141:177081. doi: 10.1093/brain/awy098

47. Juttukonda MR, Franco G, Englot DJ, Lin YC, Petersen KJ, Trujillo P, et al. White matter differences between essential tremor and Parkinson disease. Neurology. (2019) 92:e30-9. doi: 10.1212/WNL.0000000000006694

48. van der Salm SM, van der Meer JN, Nederveen AJ, Veltman DJ, van Rootselaar AF, Tijssen MA. Functional MRI study of response inhibition in myoclonus dystonia. Exp Neurol. (2013) 247:623-9. doi: 10.1016/j.expneurol.2013.02.017

49. Carbon M, Argyelan M, Eidelberg D. Functional imaging in hereditary dystonia. Eur J Neurol. (2010) 17(Suppl.1):5864. doi: 10.1111/j.1468-1331.2010.03054.x

50. Hubsch C, Roze E, Popa T, Russo M, Balachandran A, Pradeep S, et al. Defective cerebellar control of cortical plasticity in writer's cramp. Brain. (2013) 136:2050-62. doi: 10.1093/brain/awt147

51. Bologna M, Paparella G, Fabbrini A, Leodori G, Rocchi L, Hallett M, et al. Effects of cerebellar theta-burst stimulation on arm and neck movement kinematics in patients with focal dystonia. Clin Neurophysiol. (2016) 127:3472-9. doi: 10.1016/j.clinph.2016.09.008

52. Boonstra F, Florescu G, Evans A, Steward C, Mitchell P, Desmond P, et al. Tremor in multiple sclerosis is associated with cerebello-thalamic pathology. J Neural Transm. (2017) 124:1509-14. doi: 10.1007/s00702-017-1798-4

53. Loewenstein Y. A possible role of olivary gap-junctions in the generation of physiological and pathological tremors. Mol Psychiatry. (2002) 7:12931. doi: 10.1038/sj.mp.4000994

54. Boecker H, Wills AJ, Ceballos-Baumann A, Samuel M, Thompson PD, Findley LJ, et al. The effect of ethanol on alcohol-responsive essential tremor: a positron emission tomography study. Ann Neurol. (1996) 39:6508. doi: 10.1002/ana.410390515
55. Martin FC, Thu Le A, Handforth A. Harmaline-induced tremor as a potential preclinical screening method for essential tremor medications. Mov Disord. (2005) 20:298-305. doi: 10.1002/mds.20331

56. Nicoletti G, Manners D, Novellino F, Condino F, Malucelli E, Barbiroli B, et al. Diffusion tensor MRI changes in cerebellar structures of patients with familial essential tremor. Neurology. (2010) 74:988-94. doi: 10.1212/WNL.0b013e3181d5a460

57. Levy LM, Hallett M. Impaired brain GABA in focal dystonia. Ann Neurol. (2002) 51:93-101. doi: 10.1002/ana.10073

58. Benarroch EE. GABAA receptor heterogeneity, function, and implications for epilepsy. Neurology. (2007) 68:6124. doi: 10.1212/01.wnl.0000255669.83468.dd

59. Ferando I, Mody I. Interneuronal GABAA receptors inside and outside of synapses. Curr Opin Neurobiol. (2014) 26:5763. doi: 10.1016/j.conb.2013.12.001

60. Stell BM, Rostaing P, Triller A, Marty A. Activation of presynaptic GABA(A) receptors induces glutamate release from parallel fiber synapses. J Neurosci. (2007) 27:9022-31. doi: 10.1523/JNEUROSCI.1954-07.2007

61. Kralic JE, Criswell HE, Osterman JL, O’Buckley TK, Wilkie ME, Matthews $\mathrm{DB}$, et al. Genetic essential tremor in gamma-aminobutyric acidA receptor alphal subunit knockout mice. J Clin Invest. (2005) 115:7749. doi: 10.1172/JCI200523625

62. Boecker $\mathrm{H}$, Weindl A, Brooks DJ, Ceballos-Baumann AO, Liedtke C, Miederer M, et al. GABAergic dysfunction in essential tremor: an 11C-flumazenil PET study. J Nucl Med. (2010) 51:1030-5. doi: 10.2967/jnumed.109.074120

63. Pym LJ, Cook SM, Rosahl T, McKernan RM, Atack JR. Selective labelling of diazepam-insensitive GABAA receptors in vivo using [3H] Ro 15-4513. Br J Pharmacol. (2005) 146:817-25. doi: 10.1038/sj.bjp.0706392

64. Paris-Robidas S, Brochu E, Sintes M, Emond V, Bousquet M, Vandal M, et al. Defective dentate nucleus GABA receptors in essential tremor. Brain. (2012) 135:105-16. doi: 10.1093/brain/awr301

65. Handforth A, Kadam PA, Kosoyan HP, Eslami P. Suppression of harmaline tremor by activation of an extrasynaptic GABAA receptor: implications for essential tremor. Tremor Other Hyperkinet Mov. (2018) 8:546. doi: $10.5334 /$ tohm.407

66. Wallner M, Hanchar HJ, Olsen RW. Ethanol enhances alpha 4 beta 3 delta and alpha 6 beta 3 delta gamma-aminobutyric acid type A receptors at low concentrations known to affect humans. Proc Natl Acad Sci USA. (2003) 100:15218-23. doi: 10.1073/pnas.2435171100

67. Wei W, Faria LC, Mody I. Low ethanol concentrations selectively augment the tonic inhibition mediated by delta subunit-containing GABAA receptors in hippocampal neurons. J Neurosci. (2004) 24:837982. doi: 10.1523/JNEUROSCI.2040-04.2004

68. Benarroch EE. GABAB receptors: structure, functions, and clinical implications. Neurology. (2012) 78:57884. doi: 10.1212/WNL.0b013e318247cd03

69. Mishra D, Chergui K. Ethanol inhibits excitatory neurotransmission in the nucleus accumbens of adolescent mice through GABAA and GABAB receptors. Addict Biol. (2013) 18:60513. doi: $10.1111 /$ j.1369-1600.2011.00350.x

70. Zamponi GW, Striessnig J, Koschak A, Dolphin AC. The physiology, pathology, and pharmacology of voltage-gated calcium channels and their future therapeutic potential. Pharmacol Rev. (2015) 67:821-70. doi: 10.1124/pr.114.009654

71. Higgins JJ, Lombardi RQ, Pucilowska J, Jankovic J, Tan EK, Rooney JP. A variant in the HS1-BP3 gene is associated with familial essential tremor. Neurology. (2005) 64:417-21. doi: 10.1212/01.WNL.0000153481.30222.38

72. Tio M, Tan EK. Genetics of essential tremor. Parkinsonism Relat Disord. (2016) 22(Suppl.1):S176-8. doi: 10.1016/j.parkreldis.2015.09.022

73. Park YG, Park HY, Lee CJ, Choi S, Jo S, Choi H, et al. Ca(V)3.1 is a tremor rhythm pacemaker in the inferior olive. Proc Natl Acad Sci USA. (2010) 107:10731-6. doi: 10.1073/pnas.1002995107

74. Handforth A, Homanics GE, Covey DF, Krishnan K, Lee JY, Sakimura $\mathrm{K}$, et al. T-type calcium channel antagonists suppress tremor in two mouse models of essential tremor. Neuropharmacology. (2010) 59:3807. doi: 10.1016/j.neuropharm.2010.05.012 
75. Graef JD, Huitt TW, Nordskog BK, Hammarback JH, Godwin DW. Disrupted thalamic T-type Ca2+ channel expression and function during ethanol exposure and withdrawal. J Neurophysiol. (2011) 105:52840. doi: 10.1152/jn.00424.2010

76. Mu J, Carden WB, Kurukulasuriya NC, Alexander GM, Godwin DW. Ethanol influences on native T-type calcium current in thalamic sleep circuitry. J Pharmacol Exp Ther. (2003) 307:197-204. doi: 10.1124/jpet.103.053272

77. Shan HQ, Hammarback JA, Godwin DW. Ethanol inhibition of a T-type $\mathrm{Ca}(2)+$ channel through activity of protein kinase C. Alcohol Clin Exp Res. (2013) 37:1333-42. doi: 10.1111/acer.12098

78. Maltese M, Martella G, Imbriani P, Schuermans J, Billion K, Sciamanna G, et al. Abnormal striatal plasticity in a DYT11/SGCE myoclonus dystonia mouse model is reversed by adenosine A2A receptor inhibition. Neurobiol Dis. (2017) 108:128-39. doi: 10.1016/j.nbd.2017.08.007

79. Wang J, Kelly GC, Tate WJ, Li YS, Lee M, Gutierrez J, et al. Excitatory Amino acid transporter expression in the essential tremor dentate nucleus and cerebellar cortex: a postmortem study. Parkinsonism Relat Disord. (2016) 32:87-93. doi: 10.1016/j.parkreldis.2016.09.003

80. Barbagallo G, Arabia G, Novellino F, Nistico R, Salsone M, Morelli $M$, et al. Increased glutamate + glutamine levels in the thalamus of patients with essential tremor: a preliminary proton MR spectroscopic study. Parkinsonism Relat Disord. (2018) 47:57-63. doi: 10.1016/j.parkreldis.2017.11.345

81. Yu SW, Chen CM, Chen YC, Chang CW, Chang HS, Lyu RK, et al. SLC1A2 variant is associated with essential tremor in Taiwanese population. PLoS ONE. (2013) 8:e71919. doi: 10.1371/journal.pone.0071919

82. Jimenez-Jimenez FJ, Garcia-Martin E, Alonso-Navarro H, Lorenzo-Betancor O, Ortega-Cubero S, Pastor P, et al. A family study of DRD3 rs6280, SLC1A2 rs3794087 and MAPT rs1052553 variants in essential tremor. Neurol Res. (2016) 38:880-7. doi: 10.1080/01616412.2016.1210355

83. Ross JP, Rayaprolu S, Bernales CQ, Soto-Ortolaza AI, van Gerpen J, Uitti RJ, et al. SLC1A2 rs3794087 does not associate with essential tremor. Neurobiol Aging. (2014) 35:935e9-10. doi: 10.1016/j.neurobiolaging.2013.09.022

84. Jimenez-Jimenez FJ, Alonso-Navarro H, Garcia-Martin E, Agundez JA. SLC1A2 rs3794087 variant and risk for essential tremor: a systematic review and meta-analysis. Pharmacogenet Genomics. (2015) 25:5648. doi: 10.1097/FPC.0000000000000171

85. Xu Y, Cao B, Chen Y, Ou R, Wei Q, Yang J, et al. SLC1A2 rs3794087 are associated with susceptibility to Parkinson's disease, but not essential tremor, amyotrophic lateral sclerosis or multiple system atrophy in a Chinese population. J Neurol Sci. (2016) 365:96-100. doi: 10.1016/j.jns.2016.04.003

86. Tranberg M, Stridh MH, Guy $\mathrm{Y}$, Jilderos B, Wigstrom H, Weber $\mathrm{SG}$, et al. NMDA-receptor mediated efflux of $\mathrm{N}$-acetylaspartate: physiological and/or pathological importance? Neurochem Int. (2004) 45:1195-204. doi: 10.1016/j.neuint.2004.06.005

87. Louis ED, Shungu DC, Chan S, Mao X, Jurewicz EC, Watner D. Metabolic abnormality in the cerebellum in patients with essential tremor: a proton magnetic resonance spectroscopic imaging study. Neurosci Lett. (2002) 333:17-20. doi: 10.1016/S0304-3940(02)00966-7

88. Paterson NE, Malekiani SA, Foreman MM, Olivier B, Hanania T. Pharmacological characterization of harmaline-induced tremor activity in mice. Eur J Pharmacol. (2009) 616:73-80. doi: 10.1016/j.ejphar.2009.05.031

89. Rachad L, El Kadmiri E, Slassi I, El Otmani H, Nadifi S. Genetic aspects of myoclonus-dystonia syndrome (MDS). Mol Neurobiol. (2017) 54:93942. doi: 10.1007/s12035-016-9712-X

90. Xiao J, Vemula SR, Xue Y, Khan MM, Carlisle FA, Waite AJ, et al. Role of major and brain-specific Sgce isoforms in the pathogenesis of myoclonus-dystonia syndrome. Neurobiol Dis. (2017) 98:52-65. doi: 10.1016/j.nbd.2016.11.003

91. Manto M, Laute MA. A possible mechanism for the beneficial effect of ethanol in essential tremor. Eur $J$ Neurol. (2008) 15:697-705. doi: 10.1111/j.1468-1331.2008.02150.x

92. Rao PS, Bell RL, Engleman EA, Sari Y. Targeting glutamate uptake to treat alcohol use disorders. Front Neurosci. (2015) 9:144. doi: 10.3389/fnins.2015.00144

93. Iranpour A, Nakhaee N. A review of alcohol-related harms: a recent update. Addict Health. (2019) 11:129-37. doi: 10.22122/ahj.v11i2.225
94. Roze E, Lang AE, Vidailhet M. Myoclonus-dystonia: classification, phenomenology, pathogenesis, and treatment. Curr Opin Neurol. (2018) 31:484-90. doi: 10.1097/WCO.0000000000000577

95. Kinugawa K, Vidailhet M, Clot F, Apartis E, Grabli D, Roze E. Myoclonusdystonia: an update. Mov Disord. (2009) 24:479-89. doi: 10.1002/mds.22425

96. Frucht SJ, Bordelon Y, Houghton WH, Reardan D. A pilot tolerability and efficacy trial of sodium oxybate in ethanol-responsive movement disorders. Mov Disord. (2005) 20:1330-7. doi: 10.1002/mds.20605

97. Crunelli V, Emri Z, Leresche N. Unravelling the brain targets of gamma-hydroxybutyric acid. Curr Opin Pharmacol. (2006) 6:44-52. doi: 10.1016/j.coph.2005.10.001

98. Simonyan K, Frucht SJ, Blitzer A, Sichani AH, Rumbach AF. A novel therapeutic agent, sodium oxybate, improves dystonic symptoms via reduced network-wide activity. Sci Rep. (2018) 8:16111. doi: 10.1038/s41598-018-34553-x

99. Priori A, Bertolasi L, Pesenti A, Cappellari A, Barbieri S. Gammahydroxybutyric acid for alcohol-sensitive myoclonus with dystonia. Neurology. (2000) 54:1706. doi: 10.1212/WNL.54.8.1706

100. Rumbach AF, Blitzer A, Frucht SJ, Simonyan K. An open-label study of sodium oxybate in Spasmodic dysphonia. Laryngoscope. (2017) 127:14027. doi: 10.1002/lary.26381

101. Liechti ME, Quednow BB, Liakoni E, Dornbierer D, von Rotz R, Gachet MS, et al. pharmacodynamics of gamma-hydroxybutyrate in healthy subjects. $\mathrm{Br}$ J Clin Pharmacol. (2016) 81:980-8. doi: 10.1111/bcp.12863

102. Guerzoni S, Pellesi L, Pini LA, Caputo F. Drug-drug interactions in the treatment for alcohol use disorders: a comprehensive review. Pharmacol Res. (2018) 133:65-76. doi: 10.1016/j.phrs.2018.04.024

103. Martinez Botella G, Salituro FG, Harrison BL, Beresis RT, Bai Z, Blanco MJ, et al. Neuroactive steroids. 2. 3alpha-Hydroxy-3beta-methyl-21-(4-cyano1H-pyrazol-1'-yl)-19-nor-5beta-pregnan-20 -one (SAGE-217): a clinical next generation neuroactive steroid positive allosteric modulator of the (gamma-aminobutyric acid)a receptor. J Med Chem. (2017) 60:78109. doi: 10.1021/acs.jmedchem.7b00846

104. Ellenbogen A, Raines S, Kanes S. Exploratory trial results for sage-547 in essential tremor. In: 68th American Academy of Neurology Annual Meeting, AAN 2016. Vancouver, BC (2016).

105. Kaul I, Bullock A, Li S, Kanes S. SAGE-217 capsules in essential tremor: an open-label, phase 2 pilot clinical trial. In: 2nd Pan American Parkinson's Disease and Movement Disorders Congress. Miami, FL (2018).

106. Gomez-Mancilla B, Latulippe JF, Boucher R, Bedard PJ. Effect of ethosuximide on rest tremor in the MPTP monkey model. Mov Disord. (1992) 7:137-41. doi: 10.1002/mds.870070207

107. Miwa H, Koh J, Kajimoto Y, Kondo T. Effects of T-type calcium channel blockers on a parkinsonian tremor model in rats. Pharmacol Biochem Behav. (2011) 97:656-9. doi: 10.1016/j.pbb.2010.11.014

108. Gironell AJ. Marin-lahoz: ethosuximide for essential tremor: an openlabel trial. Tremor Other Hyperkinet Mov. (2016) 6:378. doi: 10.5334/ tohm.306

109. Jenner P. Treatment of the later stages of Parkinson's disease pharmacological approaches now and in the future. Transl Neurodegener. (2015) 4:3. doi: 10.1186/2047-9158-4-3

110. Leppik IZonisamide E. Chemistry, mechanism of action, and pharmacokinetics. Seizure. (2004) 13(Suppl.1):S59. doi: 10.1016/j.seizure.2004.04.016

111. Murata M, Horiuchi E, Kanazawa I. Zonisamide has beneficial effects on Parkinson's disease patients. Neurosci Res. (2001) 41:397-9. doi: 10.1016/S0168-0102(01)00298-X

112. Zesiewicz TA, Ward CL, Hauser RA, Sanchez-Ramos J, Staffetti JF, Sullivan KL. A double-blind placebo-controlled trial of zonisamide (zonegran) in the treatment of essential tremor. Mov Disord. (2007) 22:27982. doi: $10.1002 / \mathrm{mds} .21282$

113. Iwata Y, Irie S, Uchida H, Suzuki T, Watanabe K, Iwashita S, et al. Effects of zonisamide on tardive dyskinesia: a preliminary open-label trial. J Neurol Sci. (2012) 315:137-40. doi: 10.1016/j.jns.2011.12.010

114. Hainque E, Vidailhet M, Cozic N, Charbonnier-Beaupel F, Thobois S, Tranchant C, et al. A randomized, controlled, double-blind, crossover trial of zonisamide in myoclonus-dystonia. Neurology. (2016) 86:172935. doi: 10.1212/WNL.0000000000002631 
115. Tosches WA, Tisdell J. Long-term efficacy and safety of monotherapy and adjunctive therapy with zonisamide. Epilepsy Behav. (2006) 8:5226. doi: 10.1016/j.yebeh.2006.02.001

116. Dupont S, Biraben A, Lavernhe G, Marquet T, Allaf B. Management and monitoring of patients treated with zonisamide: the OZONE study. Epileptic Disord. (2013) 15:278-88. doi: 10.1684/epd.2013.0591

117. Bruno E, Nicoletti A, Filippini G, Quattrocchi G, Colosimo C, Zappia M. Zonisamide for essential tremor. Cochrane Database Systematic Rev. (2017). doi: 10.1002/14651858.CD009684.pub2

118. Qiu X, Dai Q, Sun F, Liu Y, Yang B, Xiang R, et al. Population pharmacokinetics of zonisamide after oral administration in healthy Chinese volunteers. Int J Clin Pharmacol Ther. (2016) 54:362-8. doi: 10.5414/CP202104

119. Kochak GM, Page JG, Buchanan RA, Peters R, Padgett CS. Steady-state pharmacokinetics of zonisamide, an antiepileptic agent for treatment of refractory complex partial seizures. J Clin Pharmacol. (1998) 38:16671. doi: 10.1002/j.1552-4604.1998.tb04406.x

120. Tabuchi H, Shiba S, Yasuda S, Ohnishi A, Shin JG. Pharmacokinetics of perampanel in healthy Korean, white, and Japanese Adult Subjects. Clin Pharmacol Drug Dev. (2018) 7:613-20. doi: 10.1002/cpdd.581

121. Krauss GL, Serratosa JM, Villanueva V, Endziniene M, Hong Z, French J, et al. Randomized phase III study 306: adjunctive perampanel for refractory partial-onset seizures. Neurology. (2012) 78:1408-15. doi: 10.1212/WNL.0b013e318254473a

122. Gironell A, Pascual-Sedano B, Marin-Lahoz J. Perampanel, a new hope for Essential tremor: an open label trial. Parkinsonism Relat Disord. (2019) 60:171-2. doi: 10.1016/j.parkreldis.2018.10.010

123. Martin FC, Handforth A. Carbenoxolone and mefloquine suppress tremor in the harmaline mouse model of essential tremor. Mov Disord. (2006) 21:1641-9. doi: 10.1002/mds. 20940

124. Nahab FB, Wittevrongel L, Ippolito D, Toro C, Grimes GJ, Starling J, et al. An open-label, single-dose, crossover study of the pharmacokinetics and metabolism of two oral formulations of 1-octanol in patients with essential tremor. Neurotherapeutics. (2011) 8:753-62. doi: 10.1007/s13311-0110045-1

125. Sinton CM, Krosser BI, Walton KD, Llinas RR. The effectiveness of different isomers of octanol as blockers of harmaline-induced tremor. Pflugers Arch. (1989) 414:31-6. doi: 10.1007/BF00585623
126. Bushara KO, Goldstein SR, Grimes GJ Jr, Burstein AH, Hallett M. Pilot trial of 1-octanol in essential tremor. Neurology. (2004) 62:1224. doi: 10.1212/01.WNL.0000101722.95137.19

127. Shill HA, Bushara KO, Mari Z, Reich M, Hallett M. Open-label doseescalation study of oral 1-octanol in patients with essential tremor. Neurology. (2004) 62:2320-2. doi: 10.1212/WNL.62.12.2320

128. Haubenberger D, Nahab FB, Voller B, Hallett M. Treatment of essential tremor with long-chain alcohols: still experimental or ready for prime time? Tremor Other Hyperkinet Mov. (2014) 4:232. doi: 10.5334/tohm.232

129. Nahab FB, Handforth A, Brown T, Shin C, Quesada A, Dong $\mathrm{C}$, et al. Octanoic acid suppresses harmaline-induced tremor in mouse model of essential tremor. Neurotherapeutics. (2012) 9:635-8. doi: 10.1007/s13311-012-0121-1

130. Haubenberger D, McCrossin G, Lungu C, Considine E, Toro C, Nahab FB, et al. Octanoic acid in alcohol-responsive essential tremor: a randomized controlled study. Neurology. (2013) 80:933-40. doi: 10.1212/WNL.0b013e3182840c4f

131. Voller B, Lines E, McCrossin G, Tinaz S, Lungu C, Grimes G, et al. Doseescalation study of octanoic acid in patients with essential tremor. J Clin Invest. (2016) 126:1451-7. doi: 10.1172/JCI83621

132. Lowell SY, Kelley RT, Monahan M, Hosbach-Cannon CJ, Colton RH, Mihaila D. The effect of octanoic acid on essential voice tremor: a double-blind, placebo-controlled study. Laryngoscope. (2019) 129:188290. doi: 10.1002/lary.27695

133. Hopfner F, Ahlf A, Lorenz D, Klebe S, Zeuner KE, Kuhlenbaumer G, et al. Early- and late-onset essential tremor patients represent clinically distinct subgroups. Mov Disord. (2016) 31:1560-6. doi: 10.1002/mds.26708

Conflict of Interest: The authors declare that the research was conducted in the absence of any commercial or financial relationships that could be construed as a potential conflict of interest.

Copyright (C) $2020 \mathrm{Wu}$, Tang, Chen and Cao. This is an open-access article distributed under the terms of the Creative Commons Attribution License (CC BY). The use, distribution or reproduction in other forums is permitted, provided the original author(s) and the copyright owner(s) are credited and that the original publication in this journal is cited, in accordance with accepted academic practice. No use, distribution or reproduction is permitted which does not comply with these terms. 